\title{
Efficacy of Plant Growth Promoting Rhizo Bacteria Containing Acc-Deaminase Activity for Enhancing Growth of Maize (Zea Mays L) under Salt-Stressed Conditions
}

\author{
Muhammad Arshadullah ${ }^{1 *}$, Arshad Ali ${ }^{1}$, Syed Ishtiaq Hyder ${ }^{1}$, Tariq Sultan ${ }^{1}$, \\ Aqsa Nazeer ${ }^{2}$ \\ ${ }^{1}$ Land Resources Research Institute, National Agricultural Research Centre, Islamabad, Pakistan \\ ${ }^{2}$ Department of Soil Science, Bhauddin Zakariya University, Multan, Punjab, Pakistan
}

\begin{abstract}
Salinity is one of the most brutal environmental factors limiting the productivity of crop plants because most of the crop plants are sensitive to salinity caused by high concentrations of salts in the soil, and the area of land affected by it is increasing day by day. Salinity is one of the major anthropogenic as well as environmental stresses that reduce plant growth. Maize is a plant known for food, feed, and energy value, but being a greater biomass, it may also be utilized to extract pollutants from soil. Plant growth-promoting rhizobacteria (PGPR) may act as bio fertilizer to improve plant health. Some rhizobacteria are beneficial to plants and affect plant growth positively through different mechanisms of action. Ethylene, a plant hormone, also known as a stress hormone, is released by the plant as a physiological response when exposed to a variety of different stresses including both edaphic and adaphic. Growth of maize plants behaves better under saline environment as inoculated with different rhizobial strain showing ACC Deaminaze activity due to the production of ethylene under stressed conditions. Reduction in sodium uptake by the utilization of different rhizobial strains under saline environment is a positive sign to induce salt tolerance biologically.
\end{abstract}

Keywords: Maize growth, Salinity, Ethylene, Rhizobial strains, Salt tolerance, PGPR ACC Deaminaze.

\section{INTRODUCTION}

Salinity is one of the most decisive problems and retards agriculture productions in many areas around the world as well as Pakistan (Hasegawa et a/., 2000). The beginning of 21st century is discernible by global shortage of water resources, environmental pollution and increased salinization of soil and water. Mounting human population and reduction in land available for cultivation are two intimidations for agricultural sustainability (Shahbaz and Ashraf, 2013). Salt stress causes many aspects of plant metabolism and accordingly, growth and yield are reduced. Surfeit of salt in soil solution may harmfully affect plant growth either through osmotic reticence of water uptake by roots or specific ion effects. Salinity increases the uptake of $\mathrm{Na}^{+}$, which finally outcome into decrease in uptake of $\mathrm{Ca}^{+2}$ and $\mathrm{K}^{+1}$ (Yildirim et al. 2006).Uptake and accumulation of $\mathrm{Cl}^{-1}$ may interrupt photosynthetic function through the inhibition of nitrate reeducate activity (Xu et al. 2000). Once the capacity of cells to store salts is pooped salts build up in the intercellular space leading to cell dryness and death (Sheldon et al. 2004).

Diverse environmental stresses i.e..high winds, severe temperatures, soil salinity, drought and flood have affected the production and cultivation of agricultural crops, among these soil salinity is one of the most demoralizing environmental stresses, which causes major reductions in cultivated land area, crop productivity and quality (Yamaguchi and Blumwald, 2005; Shahbaz and Ashraf, 2013). A saline soil is categorized in which the electrical conductivity (EC) of the saturation extract (ECe) in the root zone exceeds $4 \mathrm{dS} \mathrm{m} \mathrm{m}^{-1}$ at $25^{\circ} \mathrm{C}$ and $15 \%$ exchangeable sodium. The yield of most crop plants is reduced at this ECe, however, many crops reveal yield reduction at lower ECes (Munns, 2005; Jamil et al., 2011). It has been estimated that globally $20 \%$ of total cultivated and $33 \%$ of irrigated agricultural lands are afflicted by high salinity. Moreover, the salinized areas are increasing at a rate of $10 \%$ annually for various reasons, including low precipitation, high surface evaporation, weathering of native rocks, irrigation with saline water, and poor cultural practices. It has been estimated that more than $50 \%$ of the arable land would be salinized by the year 2050 (Jamil et al., 2011). 
Salt stressed soils are known to repress the growth of plants (Paul, 2012). Plants in their natural environment are colonized both by endo cellular and intracellular microorganisms (Gray and Smith, 2005). Rhizosphere microorganisms, particularly beneficial bacteria and fungi, can improve plant concert under stress environments and, consequently, enhance yield both directly and indirectly (Dimkpa et al., 2009). Some plant growth-promoting rhizobacteria (PGPR) may exert a direct stimulation on plant growth and development by providing plants with fixed nitrogen, phyto hormones, iron that has been sequestered by bacterial sidero phores, and soluble phosphate (Hayat $e t$ al., 2010). Others do this indirectly by protecting the plant against soil-borne diseases, most of which are caused by pathogenic fungi (Lutgtenberg and Kamilova, 2009). The problem of soil salinization is a curse for agricultural productivity worldwide. Crops grown on saline soils endure due to high osmotic stress, nutritional disorders and toxicities, poor soil physical conditions and reduced crop productivity. The present review stresses on the enrichment of productivity under stressed conditions and increased resistance of plants against salinity stress by use of plant growth promoting microorganisms Plant growth-promoting rhizobacteria (PGPR) may well play a significant role in the development of sustainable agriculture. These are rhizobacteria that are beneficial to plants and affect plant growth directly or indirectly through various mechanisms of action (Mantlelin and Touraine, 2004). All those bacteria inhabiting plant roots and influencing the plant growth positively by any mechanism are referred to as plant growth-promoting rhizobacteria (PGPR) (Asghar et al., 2002.).

Amid the plant hormones whose concentrations are most likely to be tainted by the PGPR include ethylene, auxin, gibberellins and cytokinin (Zahir et al., 2005). The toxic penalty of high salt concentrations on plants includes increase of root ethylene synthesis, hectic osmotic shock, and ionic imbalance (Mayak et al. 2004b).

Ethylene, a plant hormone, also known as a stress hormone, is unconfined by the plant as a physiological response when showing to a variety of different stresses including both edaphic and adaphic. Salinity can increase the rate of ethylene biosynthesis via superior levels of 1aminocyclopropane-1-carboxylic acid (ACC), which may lead to physiological changes in plant tissues. Any check on this accelerated ethylene production in plants can improve growth of plants under salt stress. Recently it has been found that bacteria containing ACC deaminase enzyme can hydrolyze the endogenous levels of ACC, an instant pioneer of ethylene, into ammonia and aketobutyrate resulting in reduced production of $\mathrm{C}_{2} \mathrm{H}_{4}$ (Hontzeas et al. 2004).

Many plant growth promoting rhizobacteria (PGPR) make possible plant growth indirectly by reducing plant pathogens or directly by facilitating the uptake of nutrients from environment. It has also been observed that plants inoculated with PGPR having different PGPR traits are more resistant to the toxic effect of stress ethylene synthesized as a result of stress conditions (Zahir et al. 2008). Different bacterial genera are vital components of soils. They are involved in various biotic activities of the soil ecosystem to make it vibrant for nutrient turn over and sustainable for crop production (Ahemad et al., 2009; Chandler et al., 2008). In reality, the bacteria living around/in the plant roots (rhizobacteria) are more flexible in transforming, mobilizing, solubilizing the nutrients compared to those from bulk soils (Hayat et al., 2010). Therefore, the rhizobacteria are the dominant deriving forces in recycling the soil nutrients and consequently, they are critical for soil fertility (Glick, 2012).

Newly, it has been exposed that certain plant growth promoting rhizobacteria having ACC-deaminase enzyme activity that changes ACC in to $\alpha$ - ketobutyrate and ammonia (Tahir et al., 2006; Arshad et al., 2007) and reduce the amount of ACC in addition to ethylene outside the germinating seeds. Ethylene is a plant hormone that is concerned in the regulation of many physiological responses. Ethylene is the most important growth hormone produced by almost all the plants, which mediates a wide range of plant responses (Arshad and Frankenberger 2002). It is produced naturally and is involved in several developmental processes ranging from seed germination to senescence. Its synthesis is fastened in response to various environmental stresses (Mayak et al. 2004a, b), particularly in plants subjected to salinity stress (Zapata et al. 2004). A sharp increase in ACC levels under stress conditions, which subsequently results in accelerated $\mathrm{C}_{2} \mathrm{H}_{4}$ synthesis, has been frequently reported (Mayak et al. 2004b; Arshad et al. 2007). Keeping in view the fact, this study was conducted to screen and evaluate rhizobacteria containing ACC deaminase for inducing salt tolerance and thus improving the growth of maize under salt-stressed conditions. 


\section{Materials AND MethodS}

The study was carried at National Agriculture Research Centre Islamabad to screen and evaluate rhizobacteria containing ACC deaminase for inducing salt tolerance and thus improving the growth of maize under salt-stressed conditions. $\left(\mathrm{ECe}=5.58 \mathrm{dS} \mathrm{m} \mathrm{m}^{-1}\right)$ as indicated in table-1. The salinity was developed by adding salts. The soil for this purpose was taken from NARC (National Agriculture Research Center). The design was completely randominzed with three repeats. Wheat seeds were inoculated with rhizo bacterial strains which were: $\mathrm{M}_{1} \mathrm{M}_{4} \mathrm{M}_{5} \mathrm{M}_{8}$ and $\mathrm{M}_{9}$. Salinity (5.58 dS m $\mathrm{m}^{-1}$ ) was artificially developed using salts. A soil sample $(0-20 \mathrm{~cm}$ depth) was collected from experimental soil before sowing of crop and fertilizers application. Plant samples were collected to investigate the effect of different rhizobial strains on the availability of nutrients to plants. Soil samples were analyzed for various physicochemical properties using standard methods (Ryan et al., 2001 and Sparks et al, 1996) and soil texture by Bouyoucous Hydrometer method Practical Agri. Chemistry Kanwar and Chopra (1959). The data obtained were subjected to statistical analysis using the STATISTIX statistical software (Version 8.1) and the mean values were compared using Least significant difference (LSD) multiple range test P: $0.5 \%$.(Steel and Torrie, 1997).

Table1. Physiochemical analysis of soil used in the experiment

\begin{tabular}{|l|l|l|}
\hline Characteristics & Unit & Values \\
\hline $\mathrm{pH}$ & - & 7.50 \\
\hline Electrical conductivity & $\left(\mathrm{dS} \mathrm{m}{ }^{-1}\right)$ & 5.58 \\
\hline Organic Matter & $(\%)$ & 0.72 \\
\hline $\mathrm{Na}(\mathrm{AB}-\mathrm{DTPA}$ & $\mathrm{ppm}$ & 150 \\
\hline $\mathrm{K}(\mathrm{AB}-\mathrm{DTPA})$ & $\mathrm{ppm}$ & 204 \\
\hline $\mathrm{P}(\mathrm{AB}-\mathrm{DTPA})$ & $\mathrm{ppm}$ & 1.63 \\
\hline $\mathrm{Ca}+\mathrm{Mg}$ & $(\mathrm{meq} / \mathrm{L})$ & 20 \\
\hline Carbonate & $(\mathrm{meq} / \mathrm{L})$ & 0.6 \\
\hline Bicarbonate & $(\mathrm{meq} / \mathrm{L})$ & 0.19 \\
\hline SAR & $\mathrm{meq} / \mathrm{L})$ & 9.98 \\
\hline Soil texture & - & Sandy Loam \\
\hline
\end{tabular}

\section{RESULTS AND DISCUSSION}

Growth of maize plants was significantly affected by different rhizobial strains containing ACC Deaminase activity under artificially developed saline conditions $\left(\mathrm{ECe}=5.58 \mathrm{dS} \mathrm{m}^{-1)}\right.$ mentioned in table-2. Plant height significantly affected by the inoculation maize seeds with different rhizobial strains under artificially saline soil i.e. $\mathrm{ECe}=5.58 \mathrm{dS} \mathrm{m}$ (Table-2). The highest plant height $(13 \mathrm{~cm})$ was gained by inoculating $M_{9}$ and lowest height in plant $(9.0 \mathrm{~cm})$ was observed in control i.e. without inoculation. This depicted that inoculation of maize seed with rhizobial strains showed better behaviour in plant height mitigating the toxic impacts of saline conditions $\left(E C e=5.58 \mathrm{dS} \mathrm{m}^{-1}\right)$. Plant fresh weight showed statistically significant results in data of wheat plants inoculated with strains under saline environment as indicated in table-2.Maximum fresh weight $\left(8.6 \mathrm{~g} \mathrm{plant}^{-1}\right)$ was attained by $M_{9}$. Remaining strains showed better fresh weight comparing with control saline conditions at $\mathrm{ECe}=5.58 \mathrm{dS} \mathrm{m}^{-1}$. Plant dry weight of maize plants also depicted similar findings as indicated in plant fresh weight. Chlorophyll content is a criterion for the citadel in plant photosynthesis. Significant findings were noted as depicted in table-2. $\mathrm{M}_{9}$ attained the highest value (49\%) which was statistically at par with $\mathrm{M}_{8}$ and $\mathrm{M}_{5}$. The lowest value (33\%) attained in control treatment. Yildirim et al. (2006) reported an enhancement of squash plant when applied directly or as a transplant under salinity stress. Inoculation of plant with ACC deaminase containing PGPR resulted in enhanced chlorophyll contents of maize as well as lettuce (Han and Lee 2005).

Table 2. Effect of AC C deaminase on maize growth under saline conditions

\begin{tabular}{|l|l|l|l|l|}
\hline Treatments & $\begin{array}{l}\text { Plant Height } \\
\left(\mathrm{cm} \mathrm{plant}^{-1}\right)\end{array}$ & $\begin{array}{l}\text { Plant fresh weight } \\
\left(\mathrm{g} \mathrm{plant}^{-1}\right)\end{array}$ & $\begin{array}{l}\text { Plant dry weight } \\
\left(\mathrm{g} \mathrm{plant}^{-1}\right)\end{array}$ & $\begin{array}{l}\text { Chlorophyll } \\
\text { contents }^{(\%)}\end{array}$ \\
\hline Control & $9.0 \mathrm{c}$ & $2.4 \mathrm{~d}$ & $0.9 \mathrm{~d}$ & $33 \mathrm{c}$ \\
\hline $\mathrm{M}_{1}$ & $10.0 \mathrm{bc}$ & $3.8 \mathrm{c}$ & $1.2 \mathrm{c}$ & $36 \mathrm{c}$ \\
\hline $\mathrm{M}_{4}$ & $11.0 \mathrm{~b}$ & $5.6 \mathrm{~b}$ & $1.7 \mathrm{~b}$ & $42 \mathrm{~b}$ \\
\hline $\mathrm{M}_{5}$ & $9.7 \mathrm{bc}$ & $3.8 \mathrm{c}$ & $1.3 \mathrm{c}$ & $48 \mathrm{a}$ \\
\hline $\mathrm{M}_{8}$ & $10.3 \mathrm{bc}$ & $3.9 \mathrm{c}$ & $1.2 \mathrm{c}$ & $49 \mathrm{a}$ \\
\hline $\mathrm{M}_{9}$ & $13.7 \mathrm{a}$ & $8.6 \mathrm{a}$ & $3.1 \mathrm{a}$ & $49 \mathrm{a}$ \\
\hline LSD $(0.5 \%)$ & 1.9 & 0.4 & 0.2 & 10 \\
\hline
\end{tabular}


Values followed by same letter(s) are statistically similar at $P=0.05$ level of significance

Salinity is one of the solemn environmental evils that cause osmotic stress and decline in plant growth and crop productivity in irrigated areas of arid and semiarid regions (Cicek and Cakirlar 2002). Plants that are treated with plant growth-promoting rhizobacteria (PGPR) containing ACC deaminase are dramatically more resistant to the deleterious effects of stress ethylene that is synthesized as a consequence of drought and salinity stresses (Mayak et al. 2004a, b). When ACC deaminase containing PGPR are bound to the developing seedling, they may act as a sink for ACC ensuring that the ethylene level does not become grand to the point where root growth is impaired (Grichko et a/., 2000). Soil microorganisms that produce the enzyme 1-aminocyclopropane-1-carboxylate (ACC) deaminase promote plant growth by sequestering and cleaving plant-produced ACC, and thereby lowering the level of ethylene in the plant (Penrose et aI., 2001). A decreased ethylene level permits the plant to be extra resistant to a wide variety of environmental stresses such as salinity, drought and metal toxicity (Glick, 2005).

Maize seed inoculated with different strains of bacteria having ACC deaminase effect on plant growth under saline conditions $\left(\mathrm{ECe}=5.58 \mathrm{dS} \mathrm{m}^{-1}\right)$. Ionic concentration of $\mathrm{P}(\%)$ in wheat plants showed significant differences among treatments (Table-3). Uptake of $\mathrm{P}(\%)$ was more $(0.2 \%)$ by $\mathrm{M}_{4}$ and control showed the lowest (0.097\%). Uptake of $\mathrm{K}(\%)$ was the highest (3.0 \%) by $\mathrm{M}_{1}$ and lowest was determined in control (Table-3). Sodium ionic concentration showed significant results among treatments (Table-3). However Na (\%) was the highest in control and lowest by the maize plant tissues inoculation by $\mathrm{M}_{4}$. This means that reduction in sodium ions in maize plants using inoculation with rhizobial strains mitigates the salinity and grows maize plants in better conditions to induce salt tolerance with the reduction of ethylene production under saline environment. Ahemad, 2012; Hayat et al., 2010; Rajkumar et al., 2010; Braud et al., 2009 investigated in their experiments that PGPR containing ACC Deaminaze excite plant growth through mobilizing nutrients in soils. Yuhashi et al., (2000) reported that reduction in levels of ACC upshot in lowering the synthesis of endogenous ethylene, which lessen the inhibitory effects of higher ethylene levels Besides this, plants that are inoculated with rhizobacteria having ACC-deaminase are more resistant to the injurious effects of stress ethylene that is produced as a result of stressed environments i.e. at high salt concentration (Kausar and Shahzad, 2006; Nadeem et al., 2007).

Table 3. Effect of ACC deaminase on the uptake of nutrients of maize plants

\begin{tabular}{|l|l|l|l|l|l|l|}
\hline Treatments & P\% & K\% & Na\% & Mn $(\mathrm{ppm})$ & Fe (ppm) & Zn $(\mathrm{ppm})$ \\
\hline Control & $0.097 \mathrm{c}$ & $2.00 \mathrm{~d}$ & $3.01 \mathrm{a}$ & $69.67 \mathrm{bc}$ & $0.04^{\text {NS }}$ & $0.038 \mathrm{c}$ \\
\hline $\mathrm{M}_{1}$ & $0.147 \mathrm{~b}$ & $3.00 \mathrm{a}$ & $1.97 \mathrm{c}$ & $70.67 \mathrm{~b}$ & 0.05 & $0.043 \mathrm{~b}$ \\
\hline $\mathrm{M}_{4}$ & $0.200 \mathrm{a}$ & $2.00 \mathrm{~d}$ & $1.94 \mathrm{c}$ & $68.00 \mathrm{c}$ & 0.04 & $0.042 \mathrm{~b}$ \\
\hline $\mathrm{M}_{5}$ & $0.143 \mathrm{~b}$ & $2.00 \mathrm{~d}$ & $1.91 \mathrm{c}$ & $76.33 \mathrm{a}$ & 0.05 & $0.051 \mathrm{a}$ \\
\hline $\mathrm{M}_{8}$ & $0.140 \mathrm{~b}$ & $2.50 \mathrm{~b}$ & $2.08 \mathrm{~b}$ & $71.33 \mathrm{~b}$ & 0.04 & $0.052 \mathrm{a}$ \\
\hline $\mathrm{M}_{9}$ & $0.087 \mathrm{~d}$ & $2.37 \mathrm{c}$ & $2.13 \mathrm{~b}$ & $69.67 \mathrm{bc}$ & 0.04 & $0.044 \mathrm{~b}$ \\
\hline LSD $(0.5 \%)$ & 0.004 & 0.01 & 0.09 & 2.22 & ------- & 0.008 \\
\hline
\end{tabular}

Values followed by same letter(s) are statistically similar at $P=0.05$ level of significance

\section{Conclusion}

Growth of maize plants behaves better under saline environment as inoculated with different rhizobial strain showing ACC Deraminaze activity due to the production of ethylene under stressed conditions. Reduction in sodium uptake by the utilization of different rhizobial strains under saline environment is a positive sign to induce salt tolerance biologically.

\section{REFERENCES}

[1] Ahemad, M ., 2012. Implications of bacterial resistance against heavy metals in bioremediation: a review. IIOABJ 3, 39-46

[2] Ahemad, M., Khan, M.S., 2009. Effect of insecticide-tolerant and plant growth promoting Mesorhizobiumon the performance of chickpea grown in insecticide stressed alluvial soils. J. Crop Sci. Biotechnol. 12, 213-222.

[3] Ahemad, M., Malik, A., 2011. Bioaccumulation of heavy metals by zinc resistant bacteria isolated from agricultural soils irrigated with waste water. Bacteriol. J. 2, 12-21. 
[4] Arshad, M. and W. T. Frankenberger Jr. 2002. Ethylene: Agricultural Sources and Applications. pp. 342. New York, Kluwer Academic Publishers.

[5] Arshad, M., and Frankenberger, W.T., Jr. 2002. Ethylene agricultural sources and application. Kluwer Academic Publishers, New York.

[6] Arshad, M., M. Saleem and S. Hussain. 2007. Perspectives of bacterial ACC-deaminase in phyto remediation. Trends in Biotechnology 25: 356-362.

[7] Arshad, M., Saleem, M., and Hussain, S. 2007. Perspective of bacterial ACC deaminase in phytoremediation. Trends Biotechnol. 25: 356-362.

[8] Asghar, H. N., Z. A. Zahir, M. Arshad, and A. Khaliq. 2002. Relationship between in vitro production of auxins by rhizobacteria and their growth promoting activities in Brassica juncea $\mathrm{L}$ . Biol. Fertil. Soils 35: 231-237..

[9] Braud, A., Je' ze ' quel, K., Bazot, S., Lebeau, T., 2009. Enhanced phytoextraction of an agricultural $\mathrm{Cr}$-, $\mathrm{Hg}$ - and $\mathrm{Pb}$-contaminated soil by bio augmentation with sideropho reproducing bacteria. Chemosphere 74, 280-286.

[10] Chandler, D., Davidson, G., Grant, W.P., Greaves, J., Tatchell, G.M., 2008. Microbial biopesticides for integrated crop manage-ment: an assessment of environmental and regulatory sustainability. Trends Food Sci. Tech. 19, 275-283

[11] Cicek N, Cakirlar H. 2002. The effect of salinity on some physiological parameters in two maize cultivars. Bulg J Plant Physiol. 28(1_2):66_74.

[12] Dimkpa, C., Weinand, T., Ash, F., 2009. Plant-rhizobacteria interactions alleviate abiotic stress conditions. Plant Cell Environ. 32, 1682-1694

[13] Glick, B.R., 2012. Plant Growth-Promoting Bacteria: Mechanisms and Applications. Hindawi Publishing Corporation, Scientifica.. Curro Microbiol.32:67-71.

[14] Glick, B.R 2005. Modulation of plant ethylene levels by the bacterial enzyme ACC deaminase. FEMS Microbiol. Letters 251: 1-7.

[15] Gray, E.J., Smith, D.L., 2005. Intracellular and extracellular PGPR: commonalities and distinctions in the plant-bacterium signaling processes. Soil Biol. Biochem. 37, 395-412.

[16] Grichko, V.P. and B.R. Glick. 2001. Amelioration of flooding stress by ACC-deaminase containing plant growth promoting bacteria. Plant Physiology and Biochemistry 39: 11-17.

[17] Grichko, V.P., B. Filey and B.R Glick. 2000. Increased ability of transgenic plant expressing the bacterial enzyme 1-aminocylopropane-1-carboxylic acid deaminase to accumulate $\mathrm{Cd}, \mathrm{Co}, \mathrm{Cu}$, $\mathrm{Ni}, \mathrm{Pb}$ and $\mathrm{Zn}$. J. Biotech. 81: 45-53.

[18] Han HS, Lee KD. 2005. Plant growth promoting Rhizobacteria effect on antioxidant status, photosynthesis, mineral uptake and growth of lettuce under soil stress. Res J Agri Biol Sci. 1(3):210_215.

[19] Hasegawa, P.M., RA Bressan, J.K. Zhu and H.J. Bohnert. 2000. Plant cellular and molecular

[20] Hasegawa, P.M., RA Bressan, J.K. Zhu and H.J. Bohnert. 2000. Plant cellular and molecular promoting rhizo bacterium Pseudomonas putida GR 12-72 that over produce indole acetic acid.

[21] Hayat, R., Ali, S., Amara, U., Khalid, R., Ahmed, I., 2010. Soil beneficial bacteria and their role in plant growth promotion: a review. Ann. Microbiol. 60, 579-598

[22] Hayat, R., Ali, S., Amara, U., Khalid, R., Ahmed, I., 2010. Soil beneficial bacteria and their role in plant growth promotion: a review. Ann Microbiol. 60, 579-598.

[23] Hontzeas N, Saleh SS, Glick BR. 2004. Changes in gene expression of canola roots induced by ACC-deaminase containing plant growth promoting bacteria. Mol Plant Microbe Interact. 17(8):865_871.

[24] Jamil, A., Riaz, S., Ashraf, M., Foolad, M.R., 2011. Gene expression profiling of plants under salt stress. Crit. Rev. Plant Sci. 30 (5), 435-458. 
[25] Kanwar, T. S. and S. L. Chopra. 1959. Practical Agricultural Chemistry. S. Chand and Co., Delhi.

[26] Kausar, R. and S.M. Shahzad. 2006. Effect of ACC-deaminase containing rhizobacteria on growth promotion of maize under salinity stress. Journal of Agriculture and Social Sciences 2: 216-218.

[27] Lutgtenberg, B., Kamilova, F., 2009. Plant-growth-promoting rhizobacteria. Annu. Rev. Microbiol. 63, 541-556.

[28] Mantelin, S. and B. Touraine. 2004. Plant growth promoting bacteria and nitrate availability: impacts on root development and nitrate uptake. J. Expt Bot. 55: 27-34

[29] Mayak, S., Tipora, T., and Glick, B.R. 2004b. Plant growthpromoting bacteria confer resistance in tomato plants to salt stress. Plant Physiol. 42: 565-572.

[30] Mayak, S., Tivosh, T., and Glick, B.R. 2004a. Plant growth promoting bacteria that confer resistance to water stress in tomatoes and peppers. Plant Sci. 166: 525-530.

[31] Munns, R., 2005. Genes and salt tolerance: bringing them together. New Phytol. 167, 645-663.

[32] Nadeem, S.M., Z.A. Zahir, M. Naveed and M. Arshad. 2007. Preliminary investigations on inducing salt tolerance in maize through inoculation with rhizobacteria containing ACCdeaminase activity. Canadian Journal of Microbiology 53: 1141-1149.

[33] Paul, D., 2012. Osmotic stress adaptations in rhizobacteria. J. Basic Microbiol. 52, 1-10.

[34] Penrose, OW., BA Moffat and B.R Glick. 2001. Determination of ACC to assess the effect of ACC to assess the effect of ACC-deaminase-containing bacteria on roots of canola seedlings. Can. J. Microbiol. 47: 77-80.

[35] Rajkumar, M ., Ae, N., Prasad, M.N.V., Freitas, H., 2010. Potential of siderophore-producing bacteria for improving heavy metal phyto extraction. Trends Biotechnol. 28, 142

[36] Ryan, J., G. Estefan and A. Rashid. 2001. Soil and Plant Analysis Laboratory Manual. International Center for Agricultural Research in the Dry Areas (ICARDA), Islamabad, Pakistan. $172 p$

[37] Shahbaz, M., Ashraf, M., 2013. Improving salinity tolerance in cereals. Crit. Rev. Plant Sci. 32, 237-249.

[38] Sheldon A, Menzies NW, Bing SH, Dalal RC. 2004. The effect of salinity on plant available water. Supersoil 2004: 3rd Australian New Zealand soil conference.

[39] Sparks, D.L., T.H. Carski, S.E. Fendorf, and C.V. IV. Toner, 1996. Kinetic methods and measurements. p. 1275-1307. In D.L. Sparks (ed.) Methods of soil analysis: Chemical methods. Soil Science Society of America, Madison, WI.

[40] Steel, R.G.D. and J.H. Torrie, 1997. Principles and Procedure of Statistics. McGraw Hill Book Co., Inc. Singapore, pp: 173-177.

[41] Tahir, M., M. Arshad, M. Naveed, Z.A. Zahir, B. Shaharoona and R. Ahmad. 2006. Enrichment of recycled organic waste with $\mathrm{N}$ fertilizer and PGPR containing ACC-deaminase for improving growth and yield of tomato. Soil and Environment 25: 105-112.

[42] Xu G, Magen H, Tarchirky J, Kafkafy U. 2000. Advances in chloride nutrition in plants. Adv Agron. 68:97-150.

[43] Yamaguchi, T., Blumwald, E., 2005. Developing salt-tolerant crop plants: challenges and opportunities. Trends Plant Sci. 10 (12), 615-620.

[44] Yildirim E, Taylor AG, Spittler TD. 2006. Ameliorative effects of biological treatments on growth of squash plants under salt stress. Scientia Hort. 111:1-6.

[45] Yuhashi, K.I., N. Ichikawa, H. Ezuura, S. Akao, Y. Minakawa, N. Nukui, T. Yasuta and K. Minamisawa. 2000. Rhizobitoxine production by Bradyrhizobium elkanii enhances nodulation and competitiveness of Macroptilium atropurpureum. Applied and Environmental Microbiology 66: $2658-2663$. 
Efficacy of Plant Growth Promoting Rhizo Bacteria Containing Acc-Deaminase Activity for Enhancing Growth of Maize (Zea Mays L) under Salt-Stressed Conditions

[46] Zahir ZA, Munir A, Asghar HN, Shaharoona B, Arshad M. 2008. Effectiveness of Rhizobacteria containing ACC deaminase for growth promotion of peas (Pisum sativum) under drought conditions. J Microbiol Biotechnol. 18(5):958-963.

[47] Zahir, A.Z., H.N. Asghar, M.J. Akhtar and M. Arshad. 2005. Precursor (L-tryptophan)-Inoculum

[48] Zahir, A.Z., H.N.Asghar, M.J.Akhtar and M.Arshad. 2005. Precursor (L-tryptophan)-Inoculum response to high salinity. Annu. Rev. Plant Physiol. Plant Mol. Biol. 51: 463-499

[49] Zahir, Z.A., A. Munir, H.N. Asghar, B. Shaharoona and M. Arshad. 2007. Effectiveness of rhizobacteria containing ACC-deaminase for growth promotion of pea (Pisum sativum) under drought conditions. Journal of Microbiology and Biotechnology 18: 958-963.

[50] Zapata, P.J., Serrano, M., Pretel, M.T., Amoros, A., and Botella, M.A. 2004. Polyamines and ethylene changes during germination of different plant species under salinity. Plant Sci. 167: 781-788.

Citation: M. Arshadullah, et al." Efficacy of Plant Growth Promoting Rhizo Bacteria Containing AccDeaminase Activity for Enhancing Growth of Maize (Zea Mays L) under Salt-Stressed Conditions", International Journal of Research Studies in Agricultural Sciences (IJRSAS), vol. 3, no. 7, p. 7, 2017, http://dx.doi.org /10.20431 /2454-6224.0307004.

Copyright: () 2017 Authors. This is an open-access article distributed under the terms of the Creative Commons Attribution License, which permits unrestricted use, distribution, and reproduction in any medium, provided the original author and source are credited. 